\title{
Changes in Serum Mineral Composition During Poxvirus Infection in Sheep and Their Lambs
}

\author{
Basaran Karademir ${ }^{1, a, *}$ \\ ${ }^{1}$ The School of Applied Sciences, I $\breve{g} d ı r$ University, 76000 Iğdır, Turkey \\ ${ }^{*}$ Corresponding author \\ A R T I C L E IN F O A B S T R A C T \\ Minerals have crucial roles in terms of vital function in the organism including hormones, enzymes, \\ Research Article $\quad$ cell formation etc. Oxidative stress and related hormones, regarding infectious diseases, affect all \\ functions of body including mineral taking, metabolism and excretion. The purpose of this study \\ was to investigate the effect of the pox disease on blood minerals composition of sheep and lambs. \\ Received : 15/07/2020 \\ Accepted : 10/08/2020 \\ This study was conducted on 20 healthy sheep, 20 poxvirus infected sheep and their lambs (Totally \\ 80 subjects). One-shot blood samples from sheep and lambs were collected and serums were \\ separated immediately. Serum mineral levels were analysed in the atomic absorption \\ spectrophotometer. In general, the level of $\mathrm{Cu}$ in infected animals was higher than in healthy ones. \\ $\mathrm{Zn}, \mathrm{Fe}, \mathrm{Mg}$ and $\mathrm{Na}$ levels of healthy animals were found higher than infected subjects. The \\ difference between healthy and infected animal groups for serum $\mathrm{Ca}$ and $\mathrm{K}$ levels was not \\ significant. Positive correlations were found between serum $\mathrm{Zn}, \mathrm{Fe}, \mathrm{Mg}$ and $\mathrm{Na}$ levels. However, a \\ negative correlation was found between $\mathrm{Cu}-\mathrm{Zn}$ and $\mathrm{Cu}$-Fe pairs. Consequently, $\mathrm{Cu}, \mathrm{Zn}, \mathrm{Fe}, \mathrm{Mg}$ and \\ $\mathrm{Na}$ levels in serum, which are vital for animal organisms, showed significant changes in sheep and \\ their lambs during poxvirus infection. To rapid healing or prevention of the diseases, mineral \\ disorders must be corrected urgently.
}

\section{Introduction}

Pox disease is an acute viral disease and seen in many animal species except dogs. It named "sheeppox" in sheep and characterized by papules, vesicles, macules, pustules and crusting on skin and mucosa. The lesions are seen on mucosa of digestive, respiratory and urogenital system and poor skin sections such as around lips, eyelids and ears and on axillar, inguinal, perineal and sub-tail regions. Pyrexia, lethargy, depression, anorexia, conjunctivitis, rhinitis, lacrimation, nasal discharge are other principal symptoms of sheeppox. The virus is usually transmitted through the skin and inhalation. However, contamination may also be caused by insect or acarus biting. Incubation period of it is 4-8 days. This infection sometimes can be fatal especially in young lambs (Diallo and Viljoen, 2007; Haller et al., 2014; Mahmoud and Khafagi, 2016; Venkatesan et al., 2014).

At that time, it is reported that serological diagnostic techniques are successfully used for detection of antibody created by the organism against sheeppox virus like other virus detection methods (Balinsky et al., 2008; Dashprakash et al., 2019; Haegeman et al., 2019)
It is well known that pox disease in general leads to physiological (oxidative) stress. Hereby, it affects metabolism and excretion of animals (Chirase et al., 1991; B Karademir, 2017; Machado et al., 2013; Orr et al., 1990; Paksoy, 2015). Stress causes an increase in the release of stress hormones, including adrenal hormones which can trigger numerous changes in the organism (Brunson et al., 2001; Caldji et al., 2000; Fenoglio et al., 2006; Yi and Baram, 1994).

Minerals are building blocks of all the tissues in the organism and found in all body fluids (extracellular, intracellular and intercellular) as electrolytes (Basaran Karademir, 2017; Karademir and Y1lmaz, 2018). They have several critical functions in animal and human organisms including oxidative and anti-oxidative metabolism, immune system, energy metabolism, redox reactions, reproductive functions, growth etc. (Khan et al., 2014; Machado et al., 2013; Obara et al., 2008; Yasui et al., 2014). They also influence all the biochemical events in the organism by entering into the structure of many enzymes and hormones (Bullen et al., 2005; Ganz and 
Nemeth, 2006; Karademir, 2006; Paksoy, 2015). They cannot be synthesized in the organism so they have to be taken from outside with food and water (McDowell, 1992).

There are a number of mechanisms involved in the absorption, evaluation and elimination of the minerals in the body. It is known that oxidative stress cause decline of some serum mineral levels based on usage of metalloenzymes. Fluctuations in serum mineral levels can cause a large number of functional disorders in the organism (Bicalho et al., 2014; Bullen et al., 2005; Ganz and Nemeth, 2006; Karademir, 2006; Paksoy, 2015).

Knowing the fluctuation of mineral concentration during pox diseases gives important information about the prognosis of the disease. Elimination of possible fluctuations may have positive effects on the course of the disease.

Due to the above reasons, in this study, it was aimed to investigate the effect of the stress caused by "Sheeppox disease" on mineral concentration.

\section{Materials and Methods}

\section{Ethical Approval}

This study was conducted pursuant to the approval of the Local Ethics Board for Animal Experiments of Kafkas University (KAÜ-HADYEK, Approval number: 2014/046) and care was taken to comply with the $3 R$ concept.

\section{Experimental Animals}

This research was carried out between January 2015 and January 2016. As a study subject, 40 lamb-born sheep (2-6 years old) and their 40 lambs (1-5 months old) were used (Totally 80 subjects). Poxvirus infection suspected sheep farms were visited. External clinic examinations and enzyme-linked immunosorbent assay (ELISA) test for sheeppox virus (Dashprakash et al., 2019; Haegeman et al., 2019) (abbexa ${ }^{\circledR}$ Cambirdge-UK) were performed on suspected animals. Seropositive sheep and their lambs, having poxvirus exanthema (around lips, eyelids and ears, and skin of inguinal, perineal and sub-tail regions) (from erythema to scabs) and other poxvirus infection signs, accepted as infected with sheep-poxvirus. Other signs of these infections were pyrexia, lethargy, loss of appetite, inflammation of the mucous membranes of the eyes and nose after these ocular and nasal discharge, salivation, acute respiratory distress, enlargement of superficial lymph nodes etc. (Diallo and Viljoen, 2007; Haller et al., 2014; Mahmoud and Khafagi, 2016; Venkatesan et al., 2014). Some lambs died approximately 10-15 days after the start of clinical symptoms of diseases. For this investigation, 20 sheep and their lambs were randomly selected from farm with poxvirus infection. 20 healthy sheep and their 20 lambs were kept as control groups. The control animals had similar breeding conditions as other animals with poxvirus infection.

Blood collections and storage: Blood samples were collected from the jugular vein into $8.5 \mathrm{ml}$ vacuumed dry tubes (BD Vakutainer ${ }^{\circledR}$, Tipkimsan, Turkey). Serum was separated from blood immediately (3500 rpm, $15 \mathrm{~min})$. The serum samples were stored at $-20^{\circ} \mathrm{C}$ up to mineral analyses.

\section{Laboratory Analyses and Chemicals}

The serum $\mathrm{Cu}, \mathrm{Zn}, \mathrm{Fe}, \mathrm{Mg}, \mathrm{Ca}, \mathrm{K}$ and $\mathrm{Na}$ levels were determined by means of Atomic Absorption Spectrophotometer (AAS) equipped with flame system (Thermo Elemental S4® - Thermo Electron Corporation, Great Britain). Deionized distilled water was used for all dilutions. Standard solutions of the minerals used for AAS were obtained from companies Fluka Chemie $\mathrm{GmbH}$ Switzerland (Cu: 61147, Zn: 96457, Mg: 63046, Ca: 21049, K: 60032, Na: 71173) and Merck KgaA, Germany (Fe: 119781). All chemicals were analytical grade.

For determination of Sheeppox virus antibody form suspected subjects' serum, commercial ELISA kids (abbexa ${ }^{\circledR}$ ) were used (abbexa Ltd. Cambirdge-UK) according to prospectus information.

\section{Device Measurement Reliability}

In order to confirm the accuracy of the measurements performed with this device, after every 5 sample measurements, standard solutions with known concentrations were measured. These data were used for the calculation of the coefficient of variation $(\mathrm{CV})$. The $\mathrm{CVs}$ determined for each mineral were as follows: $\mathrm{Cu}$ : 5,61\%, Zn: 4,42\%, Fe: 4,67\%, Mg: 1,83\%, Ca: 2,73\%, K: 3,48\% and Na: 2,86\% (Karademir, 2011, 2010).

\section{Glutaraldehyde Test (GA)}

To determine inflammation degree in sheep and lambs, GA was performed to all animals. The GA test solution mixed with fresh blood in the ration of 1/1. Coagulation time checked per 15 seconds by means of turning upsidedown of tubes. Full clotting time was recorded as the final test time. In the case of no coagulation in 15 minutes, GA test result accepted as negative and test time was recorded as 16 minutes. As a GA test solution, following mixture was used (Karademir, 2006; Karademir and Atalan, 2003);

- $\quad 5.6$ ml Glutaraldehyde mean solution (Merck S30895 027)

- $200 \mathrm{mg}$ Disodium Etilendiamin tetra asetic acid (Merck 143517)

- 900 mg Sodium Chloride (Merck 106404)

- $94.4 \mathrm{ml}$ Distilated water

\section{Statistical Analysis}

The normality test (Shapiro-Wilk test) results demonstrated that the data showed a normal distribution ( $>0.05)$ (Tabachnick and Fidell, 2013). Accordingly, Independent-Samples T-test as a parametric test was performed for comparison of groups' data. Results were expressed as Mean \pm SEM (SEM: Standard Error Mean). Correlation test was used to investigate the relationship among body temperature, GA time and serum mineral levels. A regression analysis was conducted to investigate the effect of inflammation (GA and temperature) on serum mineral levels.

\section{Results}

In infected groups, serum Cu levels $(\mathrm{P}<0.05)$ (Figure 1) and temperature findings $(\mathrm{P}<0.001)$ (Table 1-3) increased compared to healthy groups. GA results $(\mathrm{P}<0.001)$ (Table 1-3), serum $\mathrm{Zn}, \mathrm{Fe}, \mathrm{Mg}$ and $\mathrm{Na}$ levels $(\mathrm{P}<0.01)$ (Figure 2- 
5) of infected animals were decreased compered to healthy ones $(\mathrm{P}<0.05)$. Serum $\mathrm{Ca}$ and $\mathrm{K}$ levels of poxvirus infected animals were higher than healthy groups, but these increased results had no statistical significance $(\mathrm{P}>0.05)$.

The existence of a linear relationship between parameters was investigated with the correlation test. Correlation test and their statistical analyses results were given in table 4. Relationships between mineral levels with temperature and GA had been found statistical importance except Serum K. There were also significant correlations between some other mineral outcome pairs (Table 4). Relationships between mineral levels with temperature and GA had been found statistical importance except Serum K.
Temperature and GA results are closely related to inflammation on the body. Therefore, regression analyses was performed to reveal how changed serum mineral concentration according to change of these parameters. The regression equations of minerals as to GA and rectal temperature and their statistical evaluation was presented in Table 5.

Serum $\mathrm{Cu}, \mathrm{Zn}, \mathrm{Fe}, \mathrm{Mg}$ and $\mathrm{Na}$ levels investigated were illustrated in Figure $1-5$. The serum $\mathrm{Cu}$ levels increased in infected animals as to healthy ones (Figure 1).

The serum $\mathrm{Zn}, \mathrm{Fe}, \mathrm{Mg}$ and $\mathrm{Na}$ levels decreased in animals with poxvirus according to healthy groups (Figure 2, 3, 4 and 5).

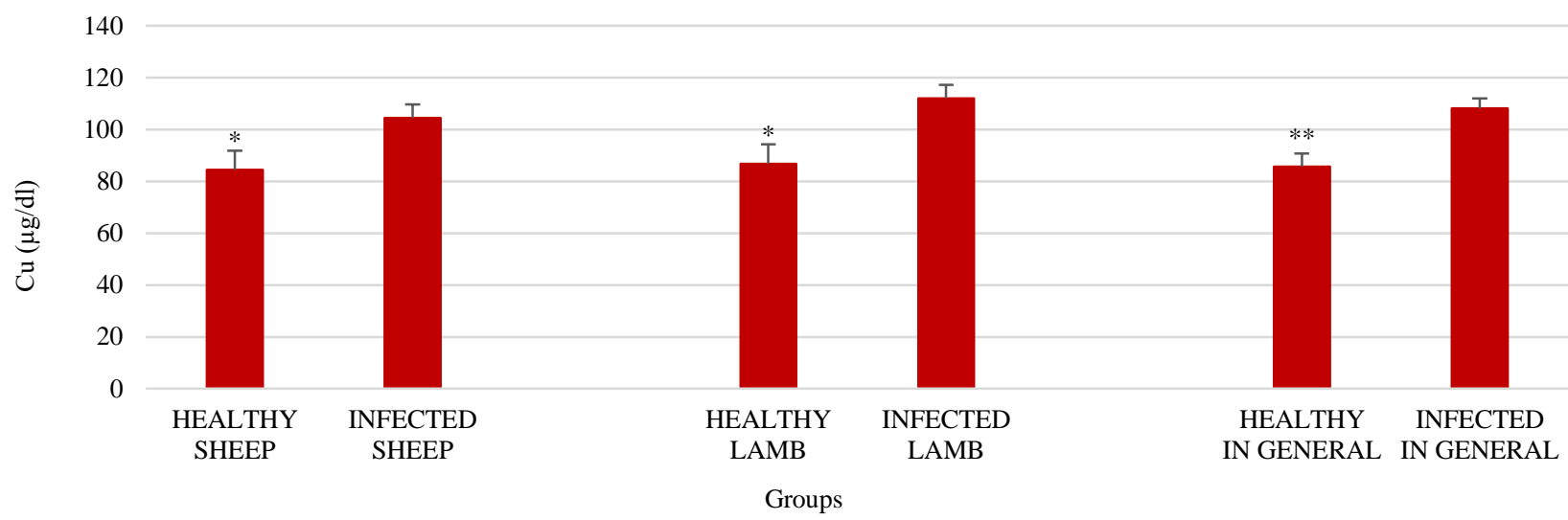

Figure 1. Serum $\mathrm{Cu}$ levels according to groups, differences between healthy and infected groups for ages were significant as *: $\mathrm{P}<0.05, * *: \mathrm{P}<0.01, \mathrm{Mean} \pm \mathrm{SEM}$

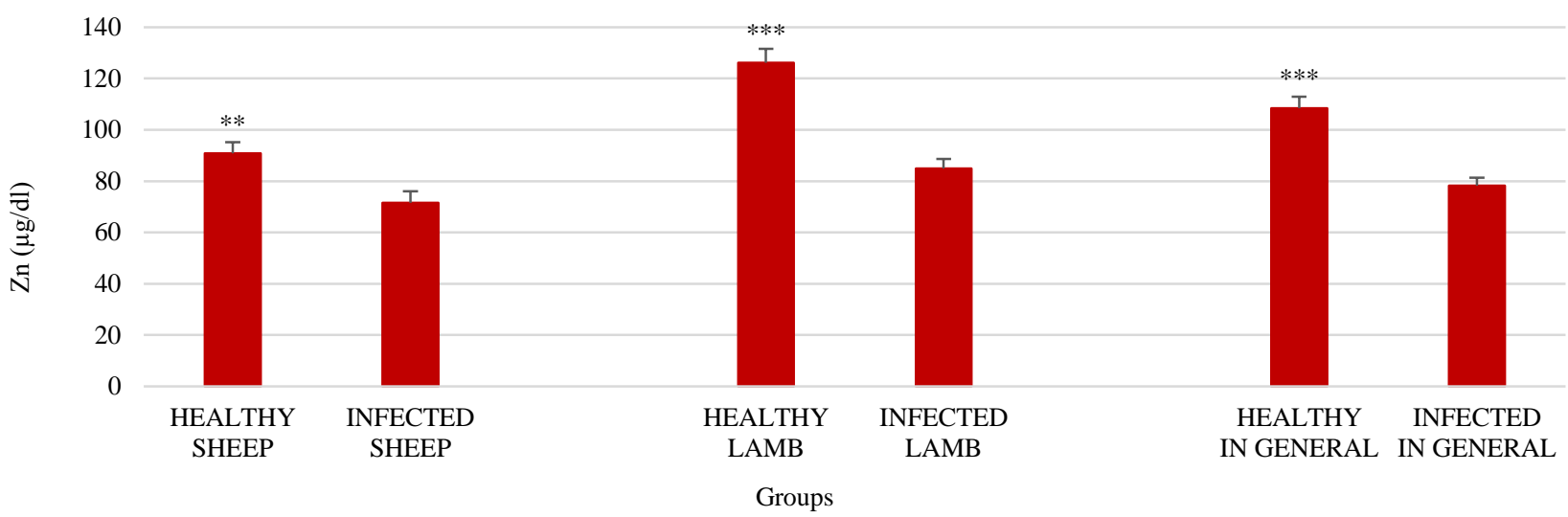

Figure 2. Serum $\mathrm{Zn}$ levels according to groups, differences between healthy and infected groups for ages were significant as $* *: \mathrm{P}<0.01, * * *: \mathrm{P}<0.001, \mathrm{Mean} \pm \mathrm{SEM}$

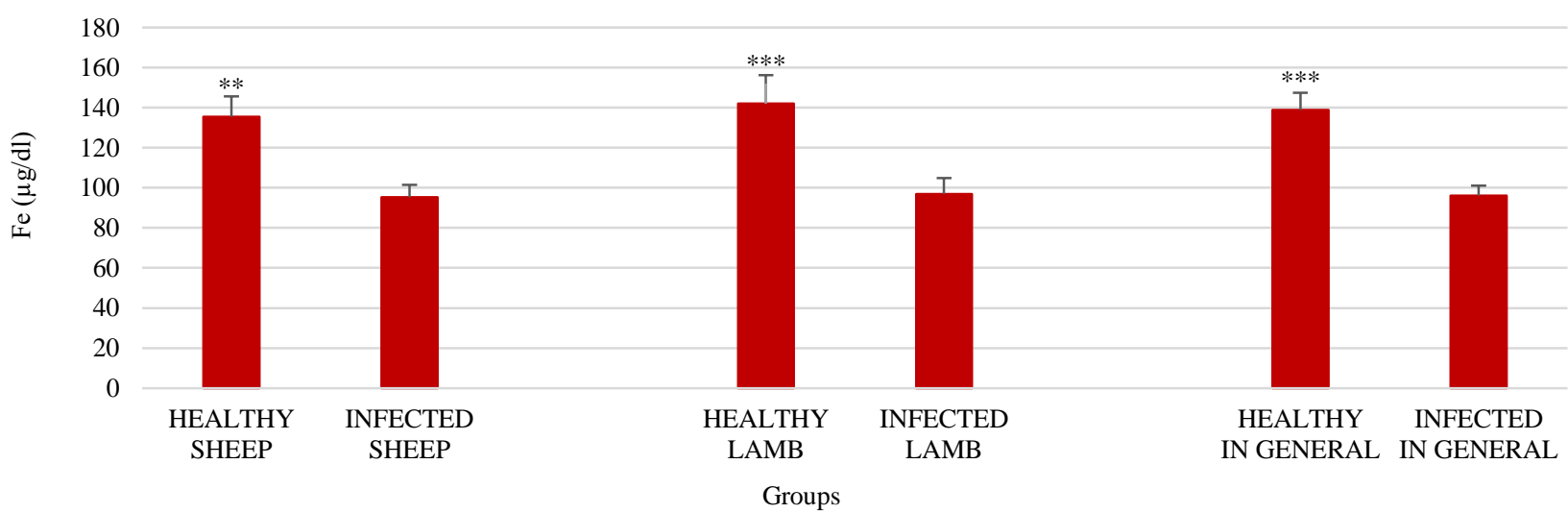

Figure 3. Serum Fe levels according to groups, differences between healthy and infected groups for ages were significant as **: $\mathrm{P}<0.01, * * *: \mathrm{P}<0.001, \mathrm{Mean} \pm \mathrm{SEM}$ 


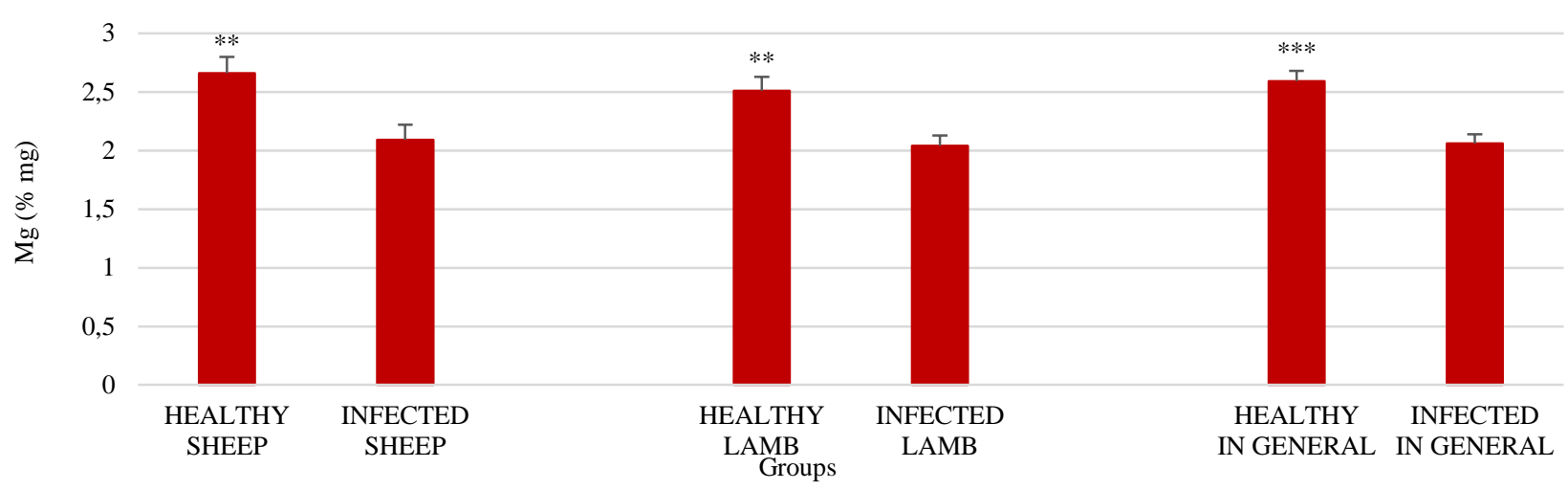

Figure 4. Serum Mg levels according to groups, differences between healthy and infected groups for ages were significant as **: $\mathrm{P}<0.01, * * *: \mathrm{P}<0.001$, Mean \pm SEM

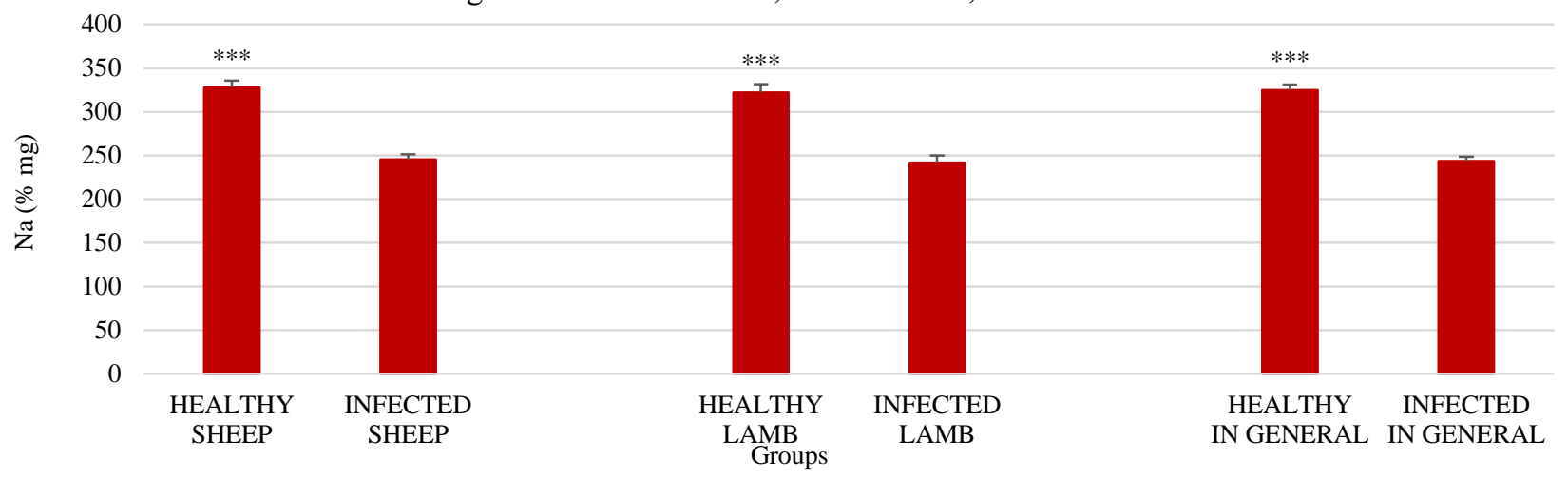

Figure 5. Serum Na levels according to groups, differences between healthy and infected groups for ages were significant as ***: $\mathrm{P}<0.001$, Mean \pm SEM

Table 1. Serum Ca and K levels, body temperature and Glutaraldehyde (GA) time of healthy and poxvirus infected sheep groups Mean \pm SEM

\begin{tabular}{l|ccc}
\hline & Healthy Sheep $(\mathrm{n}=20)$ & Infected Sheep $(\mathrm{n}=20)$ & Significance $(\mathrm{P}$ values $)$ \\
\hline $\mathrm{Ca}(\% \mathrm{mg})$ & $10.07 \pm 0.53$ & $10.96 \pm 0.54$ & 0.246 \\
$\mathrm{~K}(\% \mathrm{mg})$ & $28.37 \pm 1.65$ & $29.06 \pm 1.77$ & 0.777 \\
Temperature $\left({ }^{\circ} \mathrm{C}\right)$ & $39.08 \pm 0.10$ & $40.15 \pm 0.13$ & 0.000 \\
$\mathrm{GA}$ (min) & $16.00 \pm 0.00$ & $8.65 \pm 0.53$ & 0.000 \\
\hline
\end{tabular}

Table 2. Serum $\mathrm{Ca}$ and $\mathrm{K}$ levels, body temperature and GA time of healthy and poxvirus infected lamp groups Mean \pm SEM

\begin{tabular}{l|ccc}
\hline & Healthy Lamb $(\mathrm{n}=20)$ & Infected Lamb $(\mathrm{n}=20)$ & Significance $(\mathrm{P}$ values $)$ \\
\hline $\mathrm{Ca}(\% \mathrm{mg})$ & $11.60 \pm 0.80$ & $12.88 \pm 0.86$ & 0.280 \\
$\mathrm{~K}(\% \mathrm{mg})$ & $32.32 \pm 1.38$ & $33.02 \pm 1.42$ & 0.727 \\
Temperature $\left({ }^{\circ} \mathrm{C}\right)$ & $39.66 \pm 0.09$ & $41.36 \pm 0.06$ & 0.000 \\
$\mathrm{GA}(\mathrm{min})$ & $16.00 \pm 0.00$ & $4.88 \pm 0.53$ & 0.000 \\
\hline
\end{tabular}

Table 3. Serum $\mathrm{Ca}$ and $\mathrm{K}$ levels, body temperature and GA time of healthy and poxvirus infected groups in general Mean \pm SEM

\begin{tabular}{l|ccc}
\hline & Healthy in General $(\mathrm{n}=40)$ & Infected in General $(\mathrm{n}=40)$ & Significance $(\mathrm{P}$ values $)$ \\
\hline $\mathrm{Ca}(\% \mathrm{mg})$ & $10.83 \pm 0.49$ & $11.92 \pm 0.53$ & 0.133 \\
$\mathrm{~K}(\% \mathrm{mg})$ & $30.35 \pm 1.11$ & $31.04 \pm 1.16$ & 0.667 \\
Temperature $\left({ }^{\circ} \mathrm{C}\right)$ & $39.37 \pm 0.08$ & $40.75 \pm 0.12$ & 0.000 \\
$\mathrm{GA}(\mathrm{min})$ & $16.00 \pm 0.00$ & $6.76 \pm 0.48$ & 0.000 \\
\hline
\end{tabular}

Table 4. Pearson Correlation test results (r) between body temperature, GA time and serum mineral concentrations pairs and their

\begin{tabular}{|c|c|c|c|c|c|c|c|c|}
\hline $\mathrm{N}: 20$ & Temperature & GA & $\mathrm{Cu}$ & $\mathrm{Zn}$ & $\mathrm{Fe}$ & $\mathrm{Mg}$ & $\mathrm{Ca}$ & $\mathrm{K}$ \\
\hline GA & $-0.785 * * *$ & & & & & & & \\
\hline $\mathrm{Cu}$ & $0.287 * *$ & $-0.338 * *$ & & & & & & \\
\hline $\mathrm{Zn}$ & $-0.285^{* *}$ & $0.429 * * *$ & $-0.407 * * *$ & & & & & \\
\hline $\mathrm{Fe}$ & $-0.344 * *$ & $0.406 * * *$ & $-0.368 * *$ & $0.271 *$ & & & & \\
\hline $\mathrm{Mg}$ & $-0.481 * * *$ & $0.429 * * *$ & -0.165 & $0.320 * *$ & $0.229 *$ & & & \\
\hline $\mathrm{Ca}$ & $0.241 *$ & $-0.236^{*}$ & 0.088 & 0.119 & -0.078 & 0.080 & & \\
\hline K & 0.087 & -0.106 & 0.016 & 0.189 & -0.171 & 0.214 & $0.308 * *$ & \\
\hline $\mathrm{Na}$ & $-0.586 * * *$ & $0.701 * * *$ & -0.101 & $0.403 * * *$ & $0.307 * *$ & $0.524 * * *$ & 0.155 & 0.187 \\
\hline
\end{tabular}


Table 5. Regression equations of minerals according to GA time and rectal body temperatures

\begin{tabular}{|c|c|c|c|c|}
\hline Response & Predictors & $\begin{array}{l}\text { Regression } \\
\text { Equations }\end{array}$ & $\begin{array}{c}\text { Adjusted } \\
\text { R square }(\%)\end{array}$ & $\begin{array}{l}\text { Significance } \\
\text { (P values) }\end{array}$ \\
\hline $\mathrm{Cu}$ & & $\mathrm{Cu}=41+1.89 * \mathrm{Temp}+1.76 * \mathrm{GA}$ & 9.2 & 0.009 \\
\hline $\mathrm{Zn}$ & & $\mathrm{Zn}=-105+4.09 * \mathrm{Temp}+2.98 * \mathrm{GA}$ & 17.0 & 0.000 \\
\hline $\mathrm{Fe}$ & & $\mathrm{Fe}=213-3.38 * \mathrm{Temp}+3.44 * \mathrm{GA}$ & 14.5 & 0.001 \\
\hline $\mathrm{Mg}$ & GA, Temp & $\mathrm{Mg}=11.6-0.236 * \mathrm{Temp}+0.0155 * \mathrm{GA}$ & 21.9 & 0.000 \\
\hline $\mathrm{Ca}$ & & $\mathrm{Ca}=-7.7+0.498 * \mathrm{Temp}-0.077 * \mathrm{GA}$ & 3.9 & 0.080 \\
\hline K & & $\mathrm{K}=29.4+0.07 * \mathrm{Temp}-0.138 * \mathrm{GA}$ & 0.0 & 0.644 \\
\hline $\mathrm{Na}$ & & $\mathrm{Na}=419-5.26 * \mathrm{Temp}+6.67 * \mathrm{GA}$ & 49.5 & 0.000 \\
\hline
\end{tabular}

According to statistical comparison of healthy sheep and their lamb, serum $\mathrm{Zn}, \mathrm{Ca}$ and rectal temperature values of lambs were greater than their mothers $(\mathrm{P}<0.001)$.

In the infected herd with poxvirus, serum $\mathrm{Zn}$ level $(\mathrm{P}<0.05)$, rectal temperature and GA results $(\mathrm{P}<0.001)$ of lambs were also higher than their mothers.

There were no statistical differences between other parameters for these mentioned two groups above (in healthy and infected groups) $(\mathrm{P}>0.05)$.

\section{Discussion}

Minerals are essential for overall metabolism including immune response, cell replication, skeletal development, production, and reproductive performance etc. (Engle, 2001; Khan et al., 2014; Machado et al., 2013; Obara et al., 2008; Yasui et al., 2014). Herewith, in this study, serum mineral $(\mathrm{Zn}, \mathrm{Cu}, \mathrm{Fe}, \mathrm{Mg}, \mathrm{Ca}, \mathrm{K}$ and $\mathrm{Na}$ ) changes of sheep and their lambs infected with "sheeppox virus" were investigated.

It is known that generally diseases cause physiological (oxidative) stress on the body (Chirase et al., 1991; B Karademir, 2017; Machado et al., 2013; Orr et al., 1990; Paksoy, 2015). Stress provoke the hormonal activities of hypothalamus, hypophysis and adrenal cortex and after this circumstance, some stress hormones including cortisol and mineralo-corticoids release (Gidener and Arıc1, 2012; Yi and Baram, 1994). Mentioned hormones influence the whole body metabolism including mineral metabolism and fluid-electrolyte balance (Brunson et al., 2001; Caldji et al., 2000).

$\mathrm{Cu}$ is an essential trace element and is mainly responsible for erythropoiesis in the body, formation of myelin sheath in the central nervous system, skin and hair pigmentation, cellular respiration (B Karademir, 2017; Kuru et al., 2018). At the same time, $\mathrm{Cu}$ is incorporated into the structure of $\mathrm{Cu} / \mathrm{Zn}$ superoxide dismutase enzyme which is the enzyme of the antioxidative system. Hereby, it has a very effective role in detoxifying oxidative radicals (Karademir, 2010; Obara et al., 2008) and is also known to affect phagocytic and specific immune functions (Obara et al., 2008; Spears and Weiss, 2008). It has been reported in many times that the serum $\mathrm{Cu}$ concentration increases in cases of stress originated by diseases (Chirase et al., 1991; Karademir et al., 2009; Orr et al., 1990). Ceruloplasmin, which contains copper in the structure, is known as inflammatory markers (as an acute phase protein) and increases throughout the inflammation process. As a result of this, serum $\mathrm{Cu}$ level increases during inflammation. The main task of ceruloplasmin is to scavenges $\mathrm{Fe}^{2+}$ and free radicals, which are undesirable product of inflammation
(Gruys et al., 2005; Murata et al., 2004). The $\mathrm{Cu}$ levels of this investigation presented were similar to the findings of previous studies (Chirase et al., 1991; Karademir et al., 2009; Orr et al., 1990). The serum $\mathrm{Cu}$ levels of both infected sheep and infected lambs were significantly higher than healthy groups $(\mathrm{P}<0.001)$.

$\mathrm{Zn}$ is an essential trace element like $\mathrm{Cu}$ and has to be taken from the outside. It has been reported that many hormones (somatotropin, insulin, TSH, LH, FSH, ACTH etc.) and enzymes (carbonic anhydrase, leucine, amino peptidase, alkaline phosphatase, lactate dehydrogenase, ribonuclease etc.) contain Zn (Karademir, 2011; Karademir et al., 2017). It is known that serum Zn level fall in an inflammatory condition originated from disease (Chirase et al., 1991; Karademir et al., 2009, 2011a; B Karademir, 2017; Orr et al., 1990; Tran et al., 2004). It was observed in this study that serum zinc levels were significantly lower in patients than in healthy controls as to previous studies $(\mathrm{P}<0.001)$. The following conditions may be considered as reasons for the decrease in serum zinc level; excess consumption of $\mathrm{Zn}$ containing enzymes during inflammation for detoxifying of oxidants (Karademir et al., 2010), urinary excretion increase with the effect of mineralocorticoid secretion regarding stress, and increased metabolic activity associated with increased glucocorticoid release, which is a hormone of adrenal gland (Brunson et al., 2001; Caldji et al., 2000; Gidener and Aric1, 2012).

$\mathrm{Fe}$ is an essential trace element like $\mathrm{Cu}$ and $\mathrm{Zn}$ and involved in a large number of biochemical functions within the whole living organism. These include oxygen transport, energy metabolism, electron transfer and contribution of hemoglobin structure (Uysal, 1999). Fe also a mineral that is also too need for vital requirements of infectious microorganisms. Reduction of free Fe ions in the environment has anti-bacterial effect. In cases of microbial infection, as a kind of defense mechanism, the organism reduces the serum level of $\mathrm{Fe}$ and creates an antimicrobial effect (Bullen et al., 2005; Ganz and Nemeth, 2006; Tuna and Ulutaş, 2015; Wessling-Resnick, 2010). For this purpose, the free $\mathrm{Fe}$ is converted to haptoglobulin by complexing with hemoglobin. Another task of haptoglobulin is to remove free iron from the medium by transferring it to the liver (Tuna and Ulutaş, 2015). Haptoglobulin is known as an acute phase protein, which is elevated in the inflammatory state and used as biomarker in the diagnosis of diseases (Murata et al., 2004). Another important hormone involved in the removal of free $\mathrm{Fe}$ in the environment is hepsidin. This hormone is produced by the liver and immune system cells, and it increases in inflammatory conditions (Ganz and Nemeth, 2006; 
Wessling-Resnick, 2010). In this investigation serum $\mathrm{Fe}$ levels of healthy groups were found significantly higher than poxvirus infected animal groups $(\mathrm{P}<0.001)$. This situation of $\mathrm{Fe}$ decreasing may be related to defense mechanism of the organism against microorganism of poxvirus (Bullen et al., 2005; Ganz and Nemeth, 2006; Tuna and Ulutaş, 2015; Wessling-Resnick, 2010). From another point of view, it may be due to diuresis and speedy metabolism created by aldosterone and glucocorticoid hormones secreted from the adrenal gland during stress of the disease (Brunson et al., 2001; Caldji et al., 2000; Gidener and Arıc1, 2012).

$\mathrm{Mg}$ is the fourth mineral in the organism and the second mineral in the intracellular environment after potassium. It is an essential element required for more than three thousand enzymes to function (Görmüş and Ergene, 2003). $\mathrm{Mg}$ also has several duties including regulation of some biochemical reactions and substantial physiological functions such as, nucleic acid metabolism, protein and energy production (Wolf et al., 2007). Again, moderate to high deficiency of $\mathrm{Mg}$ can exacerbate inflammatory stress in the course of chronic diseases (Nielsen, 2010). Even so there are many unexplained role of $\mathrm{Mg}$ in the body. $\mathrm{Mg}$ mainly is absorbed in the small intestine and excreted trough renal pathway (Barbagallo and Dominguez, 2007). There are studies reporting that the $\mathrm{Mg}$ level is lowered in case of stress that occurs during the course of various diseases (Chirase et al., 1991; B Karademir, 2017; Karademir et al., 2011a, 2011b, 2009; Saraymen et al., 2003). It was observed that this study $\mathrm{Mg}$ findings was similar to findings of previous studies mentioned above. The reason for the decrease in $\mathrm{Mg}$ level can be attributed to increased catabolism and increased renal perfusion with the effect of increasing adrenal hormones in the case of stress.

Principal task of $\mathrm{Ca}$ in the body is the most important constituent of bone and dental formation. It is also reported to be involved in blood coagulation, muscle contraction, and neural conduction (McDowell, 1992). Different results were reported for serum $\mathrm{Ca}$ levels under stressful conditions related to systemic diseases or disorders. It has been reported that serum Ca level decreases in case of some toxicities and respiratory system problems (Chirase et al., 1991; Orr et al., 1990). At the same time, it was reported that serum Ca levels decreased in spontaneous coccidiosis cases (Karademir et al., 2011a) and during autohemotherapy applications in rabbits (Karademir et al., 2011b). However, in rabbits under fighting stress, it is reported that there is no statistically significant fluctuation in serum Ca level (Karademir, 2017). According to the results of this study, although Ca levels in the poxvirusinfected individuals were slightly higher than in healthy controls, this difference was statistically insignificant.

$\mathrm{K}$ is the most important intracellular, $\mathrm{Na}$ is the most important extracellular cation (Gür and Demirci, 2000). There are similar studies in the literature investigating various pathological conditions in which $\mathrm{K}$ and $\mathrm{Na}$ levels were examined. In the study of Chirase et al. (1991) serum $\mathrm{K}$ levels were increased in animals infected with infectious bovine rhinotracheitis virus and serum $\mathrm{Na}$ level remained stable. It was reported that serum $\mathrm{K}$ levels were stable and $\mathrm{Na}$ levels were lower in autohemotherapy applied rabbits (Karademir et al., 2011b) and in rabbits with spontaneous coccidiosis (Karademir et al., 2011a) than in the control group. In another study, the effect of fighting stress on serum mineral levels in rabbits was investigated (Karademir, 2017). In this study, it was reported that there was no statistical difference in serum potassium level, but there was a significant difference between groups in serum $\mathrm{Na}$ level. The serum $\mathrm{Na}$ level was lower in the beating group compared to the control group. The $\mathrm{Na}$ and $\mathrm{K}$ findings of this study were similar to our results. In case of stress, mineralocorticoid secretion increases. Urinary excretion of both cations increases with the effect of increasing mineralocorticoid hormone. Potassium in the intracellular fluid replaces the decreasing potassium in the extra cellular fluid. But there is no substitutable source for sodium. Therefore, the serum Na level found decreased in poxvirus infected sheep.

It is well known that, in case of inflammation, body temperature increase and Glutaraldehyde Test (GA) time decrease according to inflammation severity (Karademir, 2006; Karademir et al., 2017; Karademir and Atalan, 2003). In this study, body temperature and GA time data show strong negative correlation $(\mathrm{r}=-785, \mathrm{P}<0.001)$ and supported the above information (Table 4). However, serum $\mathrm{Zn}, \mathrm{Fe}, \mathrm{Mg}$ and $\mathrm{Na}$ concentrations showed positive correlation with GA and negative correlation with body temperature. In addition, serum $\mathrm{Cu}$ and $\mathrm{Ca}$ had positive correlation with body temperature and negative correlation with GA time (Table 4). This proves that in the case of inflammation regarding poxvirus infection serum $\mathrm{Cu}$ and $\mathrm{Ca}$ levels increased and serum $\mathrm{Zn}, \mathrm{Fe}, \mathrm{Mg}$ and $\mathrm{Na}$ levels decreased. The regression analyses equations showing how GA time and rectal body temperature affect serum mineral levels are shown in Table 5. As could be seen from this table, the regression equations obtained for all minerals except $\mathrm{Ca}$ and $\mathrm{K}$ were statistically significant.

\section{Conclusion}

It was observed in this study that serum mineral levels of sheep and their lambs were affected by poxvirus infection except serum $\mathrm{Ca}$ and $\mathrm{K}$ levels. Actually, serum $\mathrm{Ca}$ and $\mathrm{K}$ levels of infected subjects were higher than control ones but this difference was not significant statistically. However, there were statistical differences between infected and healthy animal groups. Serum Zn, Fe, $\mathrm{Mg}$ and $\mathrm{Na}$ levels of infected subjects were lower and $\mathrm{Cu}$ levels was higher than control group data.

From the viewpoint of veterinary practice, as a result of this investigation, it was suggested that incomplete mineral additions must be given by orally or parenterally for get rapid and good healing of pox virus infection. On the other hand, as a prevention of this disease, in support of vaccination, if there is any, the above mentioned mineral deficiencies should be eliminated before the infection.

\section{Acknowledgments}

The author would like to thank to Nejeebullah SOOMRO (Lecturer in Faculty of Medicine, The University of Sydney, Australia) for English corrections.

\section{Conflict of Interest Declaration}

The author has declared no conflict of interest. 


\section{References}

Balinsky CA, Delhon G, Smoliga G, Prarat M, French RA, Geary SJ, Rock DL, Rodriguez LL. 2008. Rapid preclinical detection of sheeppox virus by a real-time PCR assay. Journal of Clinical Microbiology, 46: 438-442.

Barbagallo M, Dominguez LJ. 2007. Magnesium metabolism in type 2 diabetes mellitus, metabolic syndrome and insulin resistance. Archives of Biochemistry and Biophysics, 458: 40-47.

Bicalho MLS, Lima FS, Ganda EK, Foditsch C, Meira EB Jr, Machado VS, Teixeira AG, Oikonomou G, Gilbert RO, Bicalho RC. 2014. Effect of trace mineral supplementation on selected minerals, energy metabolites, oxidative stress, and immune parameters and its association with uterine diseases in dairy cattle. Journal of Dairy Science, 97: 4281-4295.

Brunson K, Avishai-Eliner S, Hatalski C, Baram T. 2001. Neurobiology of the stress response early in life: evolution of a concept and the role of corticotropin releasing hormone. Molecular psychiatry, 6: 647-656.

Bullen JJ, Rogers HJ, Spalding PB, Ward CG. 2005. Iron and infection: the heart of the matter. Pathogens and Disease, 43: 325-330.

Caldji C, Diorio J, Meaney MJ. 2000. Variations in maternal care in infancy regulate the development of stress reactivity. Biological Psychiatry, 48: 1164-1174.

Chirase NK, Hutcheson DP, Thompson GB. 1991. Feed intake, rectal temperature, and serum mineral concentrations of feedlot cattle fed zinc oxide or zinc methionine and challenged with infectious bovine rhinotracheitis virus. Journal of Animal Science, 69: 4137-4145.

Dashprakash M, Venkatesan G, Kumar A, Sankar M, Arya S, Ramakrishnan MA, Pandey AB, Mondal B. 2019. Prokaryotic expression, purification and evaluation of goatpox virus ORF117 protein as a diagnostic antigen in indirect ELISA to detect goatpox. Archives of Virology, 164: 1049-1058.

Diallo A, Viljoen GJ. 2007. Genus Capripoxvirus. In: Mercer AA, Schmidt A, Weber O (editors) Poxviruses. Birkhäuser, Basel, Switzerland, pp. 167-181. ISBN: 978-3-7643-7557-7 (Online) 978-3-7643-7556-0 (Print).

Engle TE. 2001. Effects of Mineral Nutrition of Immune Function and Factors that Affect Trace Mineral Requirements of Beef Cattle. 11-13 Dec 2001, Range Beef Cow Symposium XVII., Lincoln, Nebraska, USA, pp. 87.

Fenoglio KA, Brunson KL, Baram TZ. 2006. Hippocampal neuroplasticity induced by early-life stress: functional and molecular aspects. Frontiers in Neuroendocrinology, 27: $180-192$.

Ganz T, Nemeth E. 2006. Regulation of iron acquisition and iron distribution in mammals. Biochimica et Biophysica Acta (BBA) - Molecular Cell Research, 1763: 690-699.

Gidener S, Arıcı MA 2012. Glucocorticoids. Turkiye Klinikleri Journal of Hematology Special Topics, 5: 25-33.

Görmüş S, Ergene N. 2003. The clinical significance of magnesium. Genel Tip Dergisi, 14: 69-75.

Gruys E, Toussaint MJM, Niewold TA, Koopmans SJ. 2005. Acute phase reaction and acute phase proteins. Journal of Zhejiang University Science B, 6: 1045-1056.

Gür S, Demirci E. 2000. Effect of Calcium, Magnesium, Sodium and Potassium Levels in Seminal Plasma of Holstein Bulls on Spermatological Characters. Turkish Journal of Veterinary and Animal Sciences, 24: 275-282.

Haegeman A, De Vleeschauwer A, De Leeuw I, Vidanović D, Šekler M, Petrović T, Demarez C, Lefebvre D, De Clercq K. 2019. Overview of diagnostic tools for Capripox virus infections. Preventive Veterinary Medicine, 2019 May 28;104704. DOI: 10.1016/j.prevetmed.2019.104704.

Haller SL, Peng C, McFadden G, Rothenburg S. 2014. Poxviruses and the evolution of host range and virulence. Infection, Genetics and Evolution: Journal of Molecular Epidemiology and Evolutionary Genetics in Infectious Diseases, 21: 15-40.
Karademir B. 2017. Investigation of some blood serum trace and macro mineral levels in fighting rabbits. 18-20 May 2017, University - Industry Collaboration: Sarajevo, Bosnia Herzegovina, pp: 396-404.

Karademir B. 2006. Evaluation of glutaraldehyde test in traumatic reticuloperitonitis in cattle. Indian Veterinary Jurnal, 83: 996-998.

Karademir B. 2010. Effects of fluoride ingestion on serum levels of the trace minerals $\mathrm{Co}, \mathrm{Mo}, \mathrm{Cr}, \mathrm{Mn}$ and $\mathrm{Li}$ in adult male mice. Fluoride, 43: 174-178.

Karademir B. 2011. Effects of oral zinc sulfate applications at different $\mathrm{pH}$ (ascorbic acid, vinegar of graps and distillated water) on serum zinc levels in rabbits. Ankara Üniversitesi Veteriner Fakültesi Dergisi, 58: 11-16.

Karademir B. 2017b. The effects of stress result from brucellosis up on to blood serum trace and macro mineral levels in sheep and cows. 10-13 Oct 2017, I. Internatonal Turkish Veterinary Internal Medicine Congress, Antalya, Turkey: pp 36-37.

Karademir B, Atalan G. 2003. The prevalance of traumatic reticuloperitonitis in cattle of Kars province. Veteriner Cerrahi Dergisi, 9: 26-28.

Karademir B, Ersan Y, Koc E, Orhan E, Uzun F. 2011a. Tavşanlarda kendiliğinden gelişen bağırsak koksidiyozisinin bazı serum enzim ve mineral düzeyleri üzerine etkisi. YYÜ Üniversitesi Veteriner Fakültesi Dergisi, 22: 67-70.

Karademir B, Eseceli H, Kart A. 2010. The effect of oral levothyroxine sodium on serum $\mathrm{Zn}, \mathrm{Fe}, \mathrm{Ca}$ and $\mathrm{Mg}$ levels during acute copper sulfate toxication in rabbits. Journal of Animal and Veterinary Advances, 9: 240-247.

Karademir B, Karademir G, Tarhane S, Koc E. 2009. The Effect of Oral Ampicillin Applicaitons on Liver Mineral Status. Journal of Animal and Veterinary Advances, 8: 1846-1850.

Karademir B, Koc E, Ersan Y, Uzun E, Orhan E. 2011b. Otohemoterapinin Serum Biyokimyasal Parametreleri ve Mineral Madde Düzeyleri Üzerine Etkileri. YYU Üniversitesi Veteriner Fakültesi Dergisi, 22: 23-26.

Karademir B, Yılmaz İ. 2018. E.coli (K99) kökenli buzağı ishalleri sırasında bazı iz ve makro minerallerin düzeylerinin durumları. 6-8 Nov 2018, İksad International Publishing House, Ĭgdır - Turkey, pp. 38-47.

Khan HM, Bhakat M, Mohanty TK. 2014. Influence of vitamin $\mathrm{E}$, macro and micro minerals on reproductive performance of cattle and buffaloes-A review. Agricaltural Reviev, 35: 113121.

Kuru M, Karademir B, Oral H, Uzun F. 2018. The effect of acute septic mastitis and clinical mastitis on serum levels of certain trace elements and macro minerals in cows. Erciyes Universitesi Veteriner Fakültesi Dergisi, 15: 11-16.

Machado VS, Bicalho MLS, Pereira RV. 2013. Effect of an injectable trace mineral supplement containing selenium, copper, zinc, and manganese on the health and production of lactating Holstein cows. The Veterinary Journal, 197: 451-456.

Mahmoud MA, Khafagi MH. 2016. Detection, identification, and differentiation of sheep pox virus and goat pox virus from clinical cases in Giza Governorate, Egypt. Veterinary World, 9: $1445-1449$.

McDowell LR. 1992. Minerals in animal and human nutrition. Academic Press Inc., London.

Murata H, Shimada N, Yoshioka M. 2004. Current research on acute phase proteins in veterinary diagnosis: an overview. The Veterinary Journal, 168: 28-40.

Nielsen FH. 2010. Magnesium, inflammation, and obesity in chronic disease. Nutrition Reviews, 68: 333-340.

Obara H, Tomite Y, Doi M. 2008. Serum trace elements in tubefed neurological dysphagia patients correlate with nutritional indices but do not correlate with trace element intakes: case of patients receiving enough trace elements intake. Clinical Nutrition, 27: 587-593. 
Orr CL, Hutcheson DP, Grainger RB, Cummins JM, Mock RE. 1990. Serum copper, zinc, calcium and phosphorus concentrations of calves stressed by bovine respiratory disease and infectious bovine rhinotracheitis. Journal of Animal Science, 68: 2893-2900.

Paksoy N. 201. Leptospirozisli Sı ğırlarda Bakır, Çinko ve Manganez Düzeyleri. Harran Universitesi Veteriner Fakültesi Dergisi, 4: 53-56.

Saraymen R, Kilic E, Yazar S, Saraymen B. 2003. Magnesium, copper, zinc, iron and chromium levels in sweat of boxers. Inonu Üniversitesi Tip Fakültesi Dergisi, 10: 121-125.

Spears JW, Weiss WP. 2008. Role of antioxidants and trace elements in health and immunity of transition dairy cows. The Veterinary Journal, 176: 70-76.

Tabachnick BG, Fidell LS. 2013. Using multivariate statistics, 6th edn. Pearson Inc, Boston.

Tran CD, Miller LV, Krebs NF Lei S, Hambidge KM. 2004. Zinc absorption as a function of the dose of zinc sulfate in aqueous solution. The American Journal of Clinical Nutrition, 80: $1570-1573$.

Tuna GE, Ulutaş B. 2015. Acute phase proteins as biomarkers of diseases. Journal Vetererinary Science Internal Med-Special Topics, 1: 8-18.
Uysal Z. 1999. Demir metabolizmasında, demir eksikliğinde ve demir fazlalığında yenilikler. Ankara Üniversitesi Tıp Fakültesi Mecmuası 52: 157-164.

Venkatesan G, Balamurugan V, Bhanuprakash V. 2014. TaqMan based real-time duplex PCR for simultaneous detection and quantitation of capripox and orf virus genomes in clinical samples. Journal of Virological Methods, 201: 44-50.

Wessling-Resnick M. 2010. Iron homeostasis and the inflammatory response. Annual Review of Nutrition, 30: $105-122$.

Wolf FI, Maier JAM, Nasulewicz A, Feillet-Coudray C, Simonacci M, Mazur A, Cittadini A. 2007. Magnesium and neoplasia: from carcinogenesis to tumor growth and progression or treatment. Archives of Biochemistry and Biophysics. 458: 24-32.

Yasui T, Ryan CM, Gilbert RO, Perryman KR, Overton TR. 2014. Effects of hydroxy trace minerals on oxidative metabolism, cytological endometritis, and performance of transition dairy cows. Journal of Dairy Science, 97: 3728 3738.

Yi SJ, Baram TZ. 1994. Corticotropin-releasing hormone mediates the response to cold stress in the neonatal rat without compensatory enhancement of the peptide's gene expression. Endocrinology, 135: 2364-2368. 